\title{
Equal rights. Up to What Point?
}

\author{
Xhabir Zejnuni ${ }^{1}$
}

\begin{abstract}
Today around the world is being discussed on human rights. These rights have taken and take each day more space and attention. With the evolution of today's society evolve the requirements of a part of this society for even more special recognitions. Such knowledge has to do with unions or gay marriages. For the applicants of this right, this requirement is more than natural, while for part of the other society this kind of requirement is not natural, knowing the cell of society is natural family created by the union of a man and a woman that has as ultimate goal childbearing. Demand for unions or gay marriage is not so easy to realize apparently at first sight, because then the consequences will fall upon all civil society. Also accepting gay unions or marriages, brings to amend and modify the relevant legislation which creates threatening of the balances set before. Anyone today can make choices, which he believes are most appropriate for his or her self, but not to the point that this choice affect the rest of society, as it has (also) choices which cannot or should not be resolved necessarily.
\end{abstract}

Keywords: freedom, law, rights, marriage

\section{Discrimination or discretion.}

Today, it is discussed so much on the possibility of approval of a law by the Albanian Parliament related the approval of gay marriages between persons who, according to the applicants considered as a prerequisite for rapprochement with Europe. It should be emphasized that the adoption of this law raises many issues to be resolved such as those related to: the impacts of this law in the Albanian legislation in general and in particular with the family code; the constitutionality of this law; problems that will confront the State and civil society and their endurance, etc. So the question arises whether can be married two people of the same sex. With the current law, this is not possible, because the Family Code in Article 7, par. 1 provides that "Marriage can be made between a man and a woman who have reached the age of 18" and Article 163 states that "Cohabitation is a union of fact between a man and woman living as a couple, characterized by a common life, which represents a continuity and stability character". In both articles above is excluded union between two individuals of the same sex. It is a problem that the Council of Europe insists on drafting this law, because otherwise, by not drafting this law, which brings indirect consequences sanctioning of such restrictions, would be called as a violation of rights and human freedoms. Here is not discussed that if the law is not passed, that this actually will serve as a discrimination against homosexuals, but it has to 
do with the recognition of marriages between them. Today, the marriage protects the family, and the family has a broader vision than cohabitation between two individuals of the same sex. Which is the reason that homosexuals should marry legally? If gay couples naturally can create families, on the other side they cannot have children because they are the same sex. Nobody forbids gay couples to live together without the mediation of a law, after acknowledging that on the other side yet there is no law that forbids such a union, so each individual can live with whom and how he or she wills. It should be noted that if human rights are not unlimited, this does not mean that the wishes of anyone are fulfilled beyond the moral and social suit. It does not mean that by not issuing the law on gay marriages are discriminated minorities and is violated the Constitution. Even if in Europe and in the world there are several countries that legally recognize marriages between the same-sex, this fact does not mean that Albania should follow the same path in order to respect the rights of gays, for being informed with the international laws. We must not forget the fact that Albania has not the same culture in this sensitive area as many other developed countries. In some European countries these laws have been due to the demands of gay community for marriage, while in Albania, this proposal has come from some NGOs, operating in defense of human rights. Supporters of gay marriages try initially to adopt laws against racial, ethnic, religious, sexual discrimination, and then earn the right to marry the same-sex individuals. Being gay does not mean to have special status to be protected by law, because the law protects only unchanging qualities such as color and race, ethnicity and religion, etc., but the low cannot go so far to protect the sexual orientation. If on the one hand religion can be inserted into a non-discrimination law, because it has brought the world peace and civilization and is inherited from millennia, on the other hand homosexuality is not a spiritual belief, but it is an individual choice of some particular persons, which cannot and should not have consequences on the rest of society.

There are also individuals who claim that homosexuality is inborn and as such should be recognized and protected. One of the biggest geneticists in the world, Dr. Dean Hamer although is a gay activist, after endless researches has said that "we cannot say that there is a gay gene". Even world-renowned psychiatrist, Jeffrey Satinover, in his book "Homosexuality and the Politics of Truth", denounces the fact that this disease is born.

If are adopted laws designed to protect gay, then there is a possibility that this behavior is spread and grown artificially, but also abused in some way. But whether homosexuals should not be discriminated, this fact does not mean that their behavior rises to a protected status with a non-discrimination law.

In Albania is also enabled the Ombudsman to propose the state instances allowing marriages between persons of the same sex, claiming that this action will serve as a positive example not only in Albania but also in the Balkans. Perhaps Albania will have to first give many examples in other vital areas, in order to become a positive example in the Balkans, or in Europe (!).

Although equality between citizens is one of the basic principles of the legal system, observance of this principle in practice is provided by not discriminating people for various reasons such as gender, race, religion, ethnicity, language, political opinions, religious or philosophical beliefs, economic status, etc. On the other hand even if sexual orientation is not envisaged in the Constitution of Albania, it is clear that nobody can be 
discriminated because of sexual orientation. But this fact does not constitute in turn the premise that non discrimination becomes in turn a legislative approval. Anyone can bring up the argument that the Constitution of Kosovo (2008) is more explicit in this regard, as it respects the "sexual orientation" when it states in Article 24, par. 2 entitled "Equality before the Law" that "No one shall be discriminated on the basis of race, color, sex, language, religion, political opinion or others such as national or social origin, association with a community, economic and social possession, sexual orientation, birth, disability or other personal status". Through this article indirectly is accepted the union or marriage of gay persons. We must not forget that this constitution is drafted thanks to (liberal) suggestions of Europe. But on the other hand should also be claimed that one of the reasons why the Holy Residence has not yet recognized Kosovo is exactly "the sexual orientation" inserted in the Constitution of Kosovo (!).

In the current legislation the marriage between gay persons is neither foreseen nor prevented, but this fact does not push to assume that anything that is not prohibited may be accepted.

Also it is raised another delicate issue which has to do with the fact when in a traditional couple, one partner changes sex, but without affecting the previous rapport, which is required to be proceeded further with the consent of both parties. What should be done in this case? Should intervene to separate them ${ }^{1}$ ? What if two people are in such conditions (when one is transsexual) and want to marry, how to proceed ${ }^{2}$ ?

It should be noted that homosexuality has existed in Albania even before the 90s, but in a different form from these days. The criminal law of those years has provided as a criminal offense homosexuality, but very few individuals are convicted by a court decision for consumption of this offense. This for another reason, before 90's homosexuality was considered as a gesture, which contradicted the social costume and this meant that persons with homosexual tendencies should not reveal their sexual orientation.

\section{Are the requirements of homosexuals feasible?}

Nowadays, the equality between citizens is one of the basic principles of the legal system, making that observance of this principle in practice is provided through the premises for not having discrimination between persons on different grounds such as sex, race, religion, ethnicity, language, political, religious or philosophical beliefs, economic status, etc. The question is how positive and how viable will be the adoption of a law not only to this social stratum which aspires not to be discriminated, but also to society in general, which sees with disbelief and concern this phenomenon. Of course, that everyone considers as indispensable the freedom and human dignity, but must also be seen what is required to achieve by norms against so special discrimination as homosexuality. The recognition of non-discrimination can also be the shortest way to reach out to the gay marriage and the establishment of this model in a civil status, which

1 Related the question posed above can consult N. 138.2010 decision, to the Constitutional Court of Italy.

${ }^{2}$ Strasbourg Courts, decision Goodwin v. UK (17/07/2002). 
is the ultimate goal to be achieved, as the gay movement itself has clearly stated by the advocates of this issue that they aim through minor legislative changes and step by step to reach to gay marriages. This fact is also supported William Eskridge one of the biggest advocates of gay issues, which says, "Initially should be undertaken some medium steps, such as non-discrimination laws, and then aim the ultimate goal, then gay marriage" . Human rights, such as right of speech, of assembly, of having a fair trial, etc., are also guaranteed in Albania and also have the homosexuals. The right to marry is not an individual right but a social right, which is earned by fulfilling certain criteria, the most important is the consensus between a man and a woman.

\section{Orientation of the Catholic Church.}

Even the Catholic Church states that homosexual acts are intrinsically erratic, given not only by faith but by commitment to a stable and healthy society, but also because the society and in particular the State look to the family a stable and inviolable relation. For this reason, the attempt to recognize gay couples has aroused strong reactions in Vatican, despite any signs of understanding to their very delicate situation. It should be added that the defenders of the gay movement bring in their favor the attitude of the Holy Father, Pope Francis and some of his movements on the last Synod of the Catholic Church, which raised the problem of how the Catholic Church can serve gay couples, by accepting them with respect, compassion and sensitivity, without excluding, but also now by recognizing this reality. Also, the Holy Father Pope Francis stated recently that "Homosexuals should not be marginalized, but to be integrated into society" and that "If a person is homosexual and wants to approach to 4 God, good will, who am I to judge"? Agreed, but should take into consideration the opinion of God, how much he is available to homosexuals approaching. Regarding to "gay" clerics he stressed that they should be forgiven and their sins be forgotten. His statement about homosexuality is seen as more conciliatory reaction compared with his predecessors on this issue. It is enough mentioning Pope Benedict XVI, who signed a document on 29 November 2005, through which explained that "persons with homosexual tendencies should not be priests".

Thus is affirmed the continuity of the Catholic Church by not changing its secular principles, by refusing to accept gay marriages. Even at the beginning of the Bible is talked about the creation of mankind, when God "created male and female", and then blessed them by saying: "Multiply and replenish and fill the earth" (Psalm 1, 27-28). So only by relation of a man with a woman, there is the possibility for childbearing, this birth of course is excluded in case of "marriage" between persons of the same sex. Homosexuality is considered for the first time by the Holy Seat on 29.12.1975, when with the statement "Human Persons", the Congregation for the Doctrine of the Faith condemned homosexuality, which "in any case won't get get an endorsement". Later, in the

${ }^{3}$ Eskridge N. William, Jr., "Equality Practice: Civil Unions and the Future of Gay Rights " in 2002.

${ }^{4}$ Pope Francis "Interview with reporters during his return to Brazil". 
letter "Homosexuality's Issue" on 1.10.1985, led by Cardinal Ratzinger ${ }^{5}$ all bishops of the Catholic Church stated that: "Must precise that particular inclination of the homosexual person, although it is not a sin in itself, constitutes a trend, more or less strong towards a fundamentally bad behavior from a moral standpoint. For this reason, the trend itself should be regarded as an objective disorder".

While in the letter of cardinal Joseph Ratzinger dated 07.24.1992 addressed to bishops entitled "Some considerations associated with responses to legislative proposals on non-discrimination of homosexuals" in par. 13 is indicated "To include homosexual tendency on the basis of which is illegal to discriminate, may push us to regard homosexuality as a positive source of buman rights. This is very damaging from the moment there is no right to bomosexuality, and that should not be the basis for judicial claims. Moving from recognition of bomosexuality as a factor on the basis of which it is illegal to discriminate can easily lead, if not automatically on the legislative protection and promotion of homosexuality". following, paragraph 14 continues that: "Also, there is a danger that legislation which would make homosexuality a basis for rights, can actually encourage a person with a homosexual orientation to declare his homosexuality or even to seek a partner, in order to benefit from legal provisions". These two paragraphs fully clarify the opinion of the Catholic Church and the consequences that can come in case of recognition and approval of gay marriages for the entire civil society.

Also, in 2003, the Congregation for the Doctrine of the Faith through the document "Some considerations regarding the legal recognition of unions between homosexual persons", in an attempt to prevent recognition of homosexual unions on a number of European states, in par. 2 states that "There is no basis to assimilate and stabilize analogy, even past between homosexual unions and design of God on marriage and family. Marriage is holy, while homosexual acts go against the natural law and morality".

The Catholic Church also attracts the attention of Catholic lawmakers by expressing clearly and publicly and by voting against laws that favor homosexuality.

\section{Side effects that can bring a law favoring gay marriages.}

It is known that marriage is defined as full union between husband and wife and that no one should have the authority to change this definition so holy. To change the legislation, in order to pave the way for the so-called marriage between persons of the same sex, brings social consequences, which will appear more over the time and especially when it is given (whether it happens) gay unions the right to adopt children, the right to divorce, the right of inherit, etc. It should not fall prey to the erroneous opinion that by passing a law in favor of marriages between persons of the same sex, this gesture will appear in the eyes of the world as a gesture of an advanced and civilized country. Only the protection of ethical values can guarantee a strong family and therefore a healthy society. But, there should not be abused about the debate on amending the Family Code, by selling to a fundamentally legal debate and legal obligation of Albania when required to protect the Constitution, which clearly states in Article 53, par. 1 and 2 that: "Everyone has the right to marry and have a family" and that: "Marriage and

${ }^{5}$ At that time Cardinal Ratzinger was Prefect of the Congregation for the Doctrine of the Faith. 
family enjoy special protection of the State", even though at first glance it seems that the Constitution is a bit evasive when it doesn't determine that the family is created by the marriage of a woman with a man, a fact that is used as an argument by gay marriage supporters. But, on the other hand when the Constitution states in Article 54, par. 1 that "The children, young people, pregnant women and new mothers has the right of a special protection by the State", no need to add that a woman to become pregnant should be connected with a man, because this statement will be a pure legal platitude. On the other hand, the Constitution is very clear when it states in Article 53, par. 3 that "Marriages and divorces are regulated by law". And the questions are not lacking. How then think the gay marriage supporters about the marriage and dissolution of the marriage relationship between them? Should be any special law6? Who will be the man or woman in this case? Should we make an appropriate declaration before marriage, to avoid subsequent equivocations? In this case, should we change the "classic manifestation formula of the wedding reception", regardless the marriage is performed before the civilian employees or religion representatives? It is sufficient to recall only the first verse of this event, who says: "I (so called) accept you as my wife" (for men) and "I (so called) accept you as my husband (wife)". Or the above definition will be defined by lot or by throwing a coin?

Nowadays, it has become a major problem the stability of the traditional family. It is enough to recall how many couples are divorced every day. This fact makes that most traditional couples prefer better to cohabit than to marry, by the uncertainty that can bring the future even though defended by the relevant legislation. But the tendency of gay couples is the opposite, the marriage thinking that marriage would solve every problem. It cannot be assumed that gay couple be exempt from the phenomenon so widespread nowadays as the eventual divorces.

The further question then is the problem of gay couples who want to adopt children. In this case it is a special right in relation to the possibility of marriage, as well as some serious legal order even though defend gay marriage, have excluded the right of adoption.

Another important problem has to do with the population's growth. Today in the world live about 6 billion-people, who were born thanks to the union of a woman with a man. Logic requires that a couple must make at least three children in the way that the world population grows, as if each couple has two children, then these two children would not serve in the increasing of population in general, but only in replacing their parents. And what about the case of gay couples?

\section{Compliance with international obligations.}

Proponents of gay marriage also seek to abuse the international obligations of Albania when it is thrown as evidence the recent decision of the Strasbourg Court, which considered as a violation of the European Convention on Human Rights, Greek law about coexistence, which excluded gay couples from this right. If we followed the same procedure of Strasbourg in Albania, then a similar decision will also be spoken in Albanian Family Code section 163 which sets out very clearly that "Cohabitation is a fact

\footnotetext{
${ }^{6}$ Ad hoc.
} 
union between man and woman living as a couple, characterized by a joint life, which represents a stability and continuity character". Also, the right to marry is a basic human right, well known internationally, in accordance with Articles 12 (which relates with the guaranty of private life) and 16 (which is dedicated to marriage and family) the Universal Declaration of Human Rights (1948), sections 8 (which refers to the right to respect the private and family life) and 12 (which speaks about the right to marry), the European Convention of Human Rights (1950) with Articles 7 (which relates with the respect for private and family life) and 9 (which relates to the right to marry and to found a family) of the Chard of Fundamental Rights European Union (200). This fact is affirmed in Article 18 of the Albanian Constitution which states to par. 1 that "All are equal before the law" and continues to par. 2 that "No one may be discriminated unfairly for reasons such as sex, race, religion, ethnicity, language, political opinions, religious or philosophical beliefs, economic, educational, social, or ancestry".

It should be added regarding to international obligations and respect the ECHR, Article 12 of this Convention not only reaffirms that the institution of marriage has to do with individuals of the opposite sex, but delegates to the national legislation defining the conditions for exercising such a right. Should be taken into account Articles 116, par. 27, 122, par. $1,2^{8}$ of the Constitution of Albania, that impose our legislator respect for the obligations arising from the EU and in accordance with article 14 (which refers to the prohibition of discrimination) (together with Articles 8 and 12 cited above) to European Convention of Human Rights (ECHR).

In particular, in relation to Article 8, the European Court of Human Rights has supported the notion of "private life", and the protection of personal identity not limited to the individual sphere, but extends to social life, reaching to raise it up in a positive intervention of States to fix some vulnerabilities, which prevent the full personal realization. In this regard, the decision about the judgment of Goodwin (17 .07.2002), against United Kingdom the Strasbourg Court has stated that it is contrary to the Convention the prohibition of transsexual marriage with a person of the same sex to his origin.

It should be added that in the legislation of many nations with more advanced legal culture, it is revealed the notion of family relationships such as to include same-sex couples. In fact, in some European countries ${ }^{9}$ the ban of same-sex marriages has been removed, while some other countries provide special institutes for same-sex unions similar to marriage institutes, but to exclude provisions dealing with parental authority

7 Albanian Constitution Article 116, paragraph 1 "Normative Acts having force in the entire territory of Albania are: ratified international agreements ".

8 Albanian Constitution Article 122 1. "Any ratified international agreement constitutes part of the internal legal system after it is published in the Official Gazette of the Republic of Albania. (..)".

2. "A ratified international agreement by law has priority over the laws of the country that do not agree with it".

${ }^{9}$ Low Countries, Belgium, Spain, Norway, Sweden, Portugal, Iceland, Denmark, FRAC, United Kingdom, Luxembourg. 
and adoption of children. Also, among the countries that have not yet introduced marriage or inheritance protection, there are some of those countries that provide public registration forms of actual families, including homosexual ones.

It should be added that the European Community has not legislated in matrimonial matters, but is limited to some resolution to show the criteria and principles, leaving the individual member states the possibility of adapting to the national legislation. This opportunity given to European legislators has enabled the creation of multiple forms of protection of homosexual couples.

\section{Problems arising before the Albanian legislation.}

Albanian legislation is not inconsistent with the obligations arising from international treaties, since Article 18 of the Constitution states that "All are equal before the law" and that "No one may be discriminated unfairly for reasons such as sex, race, religion, ethnicity, language, political opinions, religious or philosophical beliefs, economic situation, educational, social, or ancestry". It belongs to the Parliament the exercising of its discretion, to determine the forms of guarantee and recognition to homosexual unions. But it should be added that the concepts of family and marriage should be interpreted by taking into account not only changes in the legal system, but also the evolution of society and costumes. Constitution besides marriage is also dealt with the protection of children, ensuring equal treatment to those children born out of wedlock, treating equally with those of legitimate families ${ }^{10}$. Legitimate family and her creative goal through marriage is unlike the gay union.

So if gay marriages are allowed, then it means to fall barge Article 54 of the Constitution which refers to children, their treatment and protection. Allowing gay marriages would mean depriving the coming into life of many children. It is not so easy nowadays that the right for family for gay couples be practiced in reality and be part of legal recognition, even though in turn it's up to politicians to harmonize the relationship of citizens with the State, regardless their sexual orientation. Homosexuals with their aspirations try to justify when support the idea that: "What $i$ do with my life is not related to anyone". But their idea does not correspond to the truth, as it affects the performance of all civil society and not just a part of it. On the other hand, should be taken into account pressure groups who seek by all means to represent homosexuals for certain purposes. Family is a sacred concept and therefore it is very difficult modification of the relevant legislation, because otherwise would be violated and deviated the concept of the family, because if equated the concept of coexistence of a sex partner with the concept of family, then is put into question the future of the entire civil society. According to renowned anthropologist George Murdoch "The family is the natural social group, based on common sense, economic co-operation and reproduction". It is not so easy to propose to the higher institutions of state legislative changes to open the way gay marriages, regardless of the consequences that these changes can bring the whole legal order and then the entire civil society. If it is approved a law that regulate marriages between gay people, we need to revise the

10 Albanian's Constitution Article 54 par 2.

"Children born out of a wedlock have the same rights as the one born from marriage". 
Constitution, Family Code, Civil Code and special laws that treat the whole family. It is known then what will be the economic, social and political costs that will pay the entire civil society. Although should be denied that there exists a spirit that is changing regarding the LGBT community, thus it doesn't exist previous hatred, the legislation is not yet ready to make further steps to recognize gay marriages. Another thing is to ask non discrimination of homosexuals and something else is to officially ask permission of cohabitation or same-sex marriages.

Not always a choice that can or should find necessarily the desired solution.

\section{References.}

Egidio Forcellini "Lexicon Totius Latinitatis", 1771.

Encyclical Quadragesimo Anno, 1931.

Encyclical Pacem in Terris, 1963.

Encyclical "Deus caritas est" 2006.

European Charter of Local Autonomy.

The USA's Constitution.

The Swiss' Constitution.

Albanian's Constitution.

Germany's Basic Law.

Law no. 10119 dated 23.04.2009, "On Territorial Planning.

EU Treaty. 
